\title{
Costas Douzinas, Human Rights and Empire. The Political Philosophy of Cosmopolitanism
}

\section{Routledge-Cavendish, London, 2007}

\section{Wouter Werner}

Today, to use Richard Rorty's expression, "human rights are a fact of the world". 1 Following the end of the Cold war, human rights gained prominence in international law, in (international) legal and political theory as well as in popular parlance. Moreover, human rights have increasingly entered the corridors of power. Wars have been fought in their name, military alliances have redefined their core business in terms of human rights, while large scale reconstructions of domestic societies have been undertaken for the sake of humanity. After 2001, the link between human rights and (international) security became even closer. The Bush government, for example, has casually identified the lack of human rights protection by 'failed' or 'rogue' States as an issue of homeland security, thus merging the agenda of counterterrorism with the agenda of humanitarism.

Costas Douzinas' latest book, 'Human Rights and Empire', studies the relation between human rights and the wars that are carried out in their name. Building on insights already developed in, inter alia, 'The End of Human Rights', 2 Douzinas sets out to save the critical potential of human rights in the face of their incorporation in imperialistic projects. In this context, one of the focal points of 'Human Rights and Empire' is the political philosophy of cosmopolitanism. Throughout history, Douzinas argues, different versions of cosmopolitanism have started as universalistic critiques of local injustices, only to end up as ideologies of imperial rule. Thus, critical theories of cosmopolitanism developed by the Stoics proved useful for the Macedonian and Roman imperial designs, while modernist theories of cosmopolitanism and civilization were taken up in attempts to defend,

\footnotetext{
${ }_{1}$ Richard Rorty, Human Rights, Rationality and Sentimentality, 116. Rorty here popularises the formulation of Ernesto Rabossi, La theoría de los Derechos humanos naturalizada, 5 Revista del Centro de Estudios Constitucionales (1990), 159.

2 Costas Douzinas, The End of human Rights, Oxford Hart, 2000.
}

W. Werner $(\bowtie)$

Vrije Universiteit Amsterdam, Amsterdam, The Netherlands

e-mail:w.werner@rechten.vu.nl 
for example, French expansion. According to Douzinas, contemporary (liberal) theories of cosmopolitanism do not fare any better. The core of this argument is developed from a critique of Habermas' defence of the 1999 NATO bombings of Yugoslavia (the 'Kosovo war'). While Habermas admitted that the war lacked sufficient backing in positive international law, he nevertheless regarded it as a legitimate action, because it anticipated and furthered the emergence of a cosmopolitan, constitutional legal order. In this way, Habermas offered a more thorough expression of a position taken by several international lawyers, who acknowledged the illegality of the war, but argued that is should be regarded as 'morally justified'. While international lawyers generally stopped short of spelling out the specific grounds of the latter claim, Habermas tried to embed the NATO actions in a moral theory of cosmopolitanism - as well as in a narrative of progress. Douzinas has little difficulties criticising such cosmopolitan defences of the Kosovo war. Not only are they based on a rather simplified reading of the conflict itself and a lack of attention for the downsides of the NATO operation, they also run the risk of de-formalising international law; replacing international legal obligations by unmediated moral imperatives to be protected by those in power. ${ }^{3}$ Echoing Schmitt, Douzinas speaks out against such moralisation of international politics, in which force is used to protect allegedly neutral values against those who violate the imperatives of humanity.

Douzinas' critique, however, extends beyond the ways in which several liberal international lawyers and political philosophers have sought to defend the use of force against Yugoslavia. His aim is to criticise contemporary (liberal) cosmopolitanism in general; a cosmopolitanism that he regards as "the geopolitical framework of the new millennium" (177) and that, in its institutionalised form, "risks becoming the normative gloss of globalised capitalism at its imperial stage" (p. 176). Given the harshness of such judgments, it is remarkable that 'Human Rights and Empire' does not contain a more elaborate discussion of some of the main contemporary representatives of liberal cosmopolitanism. The works of Thomas Pogge or Alan Buchanan, for example, are not even mentioned in the book. It would be interesting to see how Douzinas' thesis that liberal cosmopolitanism facilitates the global capitalist structure relates to Pogge's critique of the ways in which existing global economic structures violate the rights of the poor. Another point that could add interesting perspectives to Douzinas' reading of the rise of cosmopolitanism is the role of non-Western countries in the incorporation of universal values in the international legal system. In 'Human Rights and Empire' the non-Western world mainly appears as the target of interventions that are legitimised by universal values. Post-1945 developments, however, show that many Third World States played a more active role in the incorporation of universal values in international legal system. Despite sometimes stern Western opposition, they have struggled for the recognition of universal values, e.g. in the fields of international development law or peace and security law.

\footnotetext{
3 Ironically, this was exactly the critique of Habermas on the 2003 Iraq intervention- as discussed by Douzinas at $170,171$.
} 
In the last chapter, Douzinas formulates his own version of cosmopolitanism; the cosmopolitanism to come. Its basis is the recognition of the other as a single and unique cosmos (p. 294). Cosmopolitanism, then, becomes a radical desire of being together, based on the principle of "the other as singular, unique finite being putting me in touch with infinite otherness, the other in me and myself in the other" (p. 296). There is no doubt that Douzinas' cosmopolitanism to come contains a challenging and appealing call to return to the ancient ideals of cosmopolitanism. Yet, it also raises questions of a more practical nature. Throughout the book, Douzinas critiques international human rights law for its irrelevance in the face of violations of human dignity. He argues that for victims of such violations "human rights treaties, conventions, commissions and reports are a gigantic irrelevance" (p. 14). In similar fashion, Douzinas makes fun of human rights conferences that take place in "an air of self-satisfied irrelevance" and human rights experts, international lawyers and diplomats for whom the only personal experience with human rights violations "is being served a bad bottle of wine at their working lunches" (p. 14). While such statements make a good read (and, to be sure, Douzinas' book is a good read), they also raise the stakes for Douzinas' own position. Sure, international human rights law is deeply underdetermined, often silenced in the face of gross violations and embedded in existing political structures. However, there is also an impressive record of successes for the (liberal) human rights movement in giving voice to those whose rights are violated. How would Douzinas' cosmopolitanism-to-come fare in the same situations? Would it be possible for such a position not to become another "gigantic irrelevance" and yet to prevent its reformulation into imperialistic scripts? Hopefully, Douzinas will in the future engage with such questions and further elaborate his theory of cosmopolitanism that is to come.

Open Access This article is distributed under the terms of the Creative Commons Attribution Noncommercial License which permits any noncommercial use, distribution, and reproduction in any medium, provided the original author(s) and source are credited. 